\title{
QUANTUM PATENT MECHANICS
}

\author{
by \\ Dan L. Burk* \\ Mark A. Lemley**
}

Determining the meaning of patent claims necessarily requires a judge to break the text of a claim into discrete "elements" or units of text corresponding to the elements or units that comprise the claimed invention, essentially organizing the language of the claims into "chunks" or "quanta" of text. Define an element narrowly-limit it to a single word, say-and you will tend to narrow the resulting patent. By contrast, defining an element broadly tends to broaden the patent.

For each discrete packet identified, the courts must determine the meaning of the constituent words. They can assign those words definitions that range from narrow, specific meanings to broad, general meanings. In determining the meaning of terms within a particular element, judges practicing patent claim interpretation are engaged in an exercise that to some degree resembles the famous "levels of abstraction test" articulated by Judge Learned Hand for analysis of infringement under copyright law's "idea/expression" doctrine.

There are no hard and fast standards in the law by which to make the "right" decision as to either the size of the textual element or the level of abstraction at which it will be evaluated. Indeed, the indeterminacy is so acute that courts generally don't even acknowledge that they are engaging in either inquiry. They define an element almost arbitrarily, and even when judges disagree as to the proper definition they offer no principled basis for doing so. The problem may be worse than a simple failure to acknowledge subconscious decisions that affect the scope of a

* Oppenheimer, Wolff \& Donnelly Professor of Law, University of Minnesota.

** William H. Neukom Professor of Law, Stanford Law School; Director, Stanford Program in Law, Science and Technology; of counsel, Keker \& Van Nest LLP, San Francisco, California.

(C) 2005 Dan L. Burk \& Mark A. Lemley. Thanks to Rochelle Dreyfuss, Daralyn Durie, Rose Hagan, Tim Holbrook, Scott Kieff, Jeff Lipshaw, Kimberly Moore, Craig Nard, Judge Randy Rader, Hal Wegner, and participants in the Lewis \& Clark Law School Fall Forum, entitled "Markman v. Westview Instruments: Lessons from a Decade of Experience," and a program at Stanford Law School for comments on an earlier draft. We apologize to Rochelle Dreyfuss, who hates our physics metaphors and to whom we have now done this twice. 
patent, however. This indeterminacy may well be inherent in the process of mapping words to things, as modern literary theorists suggest. While courts purport to rely on the "ordinary" or "plain" meaning of the words of a patent claim, there may simply be no such thing.

If we can't define the "metes and bounds" of the invention in any meaningful way, we might instead start with the patentee's invention itself, construing patent claims narrowly and in light of the actual invention when the claim terms are ambiguous. Courts could then supplement this narrower claim construction with a doctrine of equivalents analysis, which would permit them to decide how broadly to apply the principle of the invention. But for this approach to work, courts must apply the doctrine of equivalents with an eye towards proper protection, rather than cabining it with formal rules.

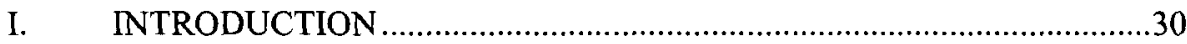

II. LEVELS OF ABSTRACTION IN CLAIM CONSTRUCTION................32

III. THE SIZE OF ELEMENTS ...........................................................41

IV. THE SEARCH FOR DEFINITE MEANING ......................................46

A. How Quanta and Abstractions Affect Patent Decisions ......................46

B. Is There a Right Answer? ..........................................................49

C. Dealing With the Lack of a Right Answer.......................................52

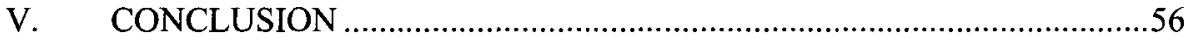

\section{INTRODUCTION}

The classic formulation of patent claim interpretation and infringement analysis requires courts to discern the elements of a claimed invention within an accused device, either literally or by equivalents. 'Since the decision of the United States Supreme Court in Markman v. Westview Instruments, Inc., ${ }^{2}$ the responsibility for this process has been split between judge and jury, with judges assigned the duty of finding the meaning of the claims. ${ }^{3}$ Determining that meaning necessarily requires the judge to break the text of a claim into discrete "elements" or units of text corresponding to the elements or units that comprise the claimed invention--essentially, organizing the language of the claims into "chunks" or "quanta" of text. The doctrine of equivalents also lends itself to grouping claim elements into either small discrete units or larger conglomerate units. These textual quanta can be either very coarse or very finegrained, grouping larger or smaller collections of limitations into descriptive units. Define an element narrowly-limit it to a single word, say-and you will tend to narrow the resulting patent, because to prove infringement the patentee must show that each word has a corresponding structure in the accused device. By contrast, defining an element broadly tends to broaden the patent, because it permits the text to read on a greater range of accused devices.

1 See Autogiro Co. of Am. v. United States, 384 F.2d 391 (Ct. Cl. 1967) (reciting the steps of claims interpretation).

2517 U.S. 370 (1996).

3 Id. at 384. 
For each discrete packet identified, the courts must determine the meaning of the constituent words. They can assign those words definitions that range from narrow, specific meanings, to broad, general meanings. Much as the quantized wave packets of particle physics may exist at different energy levels or orbitals, ${ }^{4}$ the textual quanta in patent claims may be assigned to different levels of generality. In determining the meaning of terms within a particular element, judges practicing patent claim interpretation are engaged in an exercise that to some degree resembles the famous "levels of abstraction test" articulated by Judge Learned Hand for analysis of infringement under copyright law's "idea/expression" doctrine. ${ }^{5}$ They can read a term abstractly, so that a "fastener" becomes anything that attaches two other things together, or they can read the same term more concretely, defining a fastener to be a particular type of connector such as a nail or a U-bolt. Or they may choose a level in between.

These two decisions interact. Defining textual elements at a high level of abstraction may counterbalance a decision to break the patent into small rather than large quanta, and vice versa. On the other hand, where the two decisions point in the same direction, they can have a dramatic influence on the scope of a patent. A patent with claims broken into small quanta, each of which is construed at a low level of abstraction, protects its owner against little more than exact duplication of the preferred embodiment. By contrast, a patent with claims broken into large quanta construed at a high level of abstraction will be broad indeed.

More important, and more problematic, there are no hard and fast standards in the law by which to make the "right" decision as to either the size of the textual element or the level of abstraction at which the element will be evaluated. Indeed, the indeterminacy is so acute that courts generally don't even acknowledge that they are engaging in either inquiry. Courts define an element almost arbitrarily, and even when judges disagree as to the proper definition they offer no principled basis for doing so. Judges argue over the procedures to be used and sources to consult in deciding what particular elements mean, but rarely look through to the underlying question of how broadly a particular term should be understood. Cases that do not confront these issues directly cannot be expected to provide any consistent guidance in deciding them.

The problem may be worse than a simple failure to acknowledge subconscious decisions that affect the scope of a patent, however. This indeterminacy may well be inherent in the process of mapping words to things, as modern literary theorists suggest. While courts purport to rely on the

4 See J. Rex Goates et Al., General Chemistry: TheOry \& Description 22-23, 357-61 (1981). Unlike the quanta of physics, however, there are no hard and fast levels into which any given definition must fall. Thus, the analogy to quanta is imperfect. Still, the analogy is useful because it helps us understand that identifying a unit does not tell us everything we need to know about that unit: we must still understand the level or state in which the unit resides.

${ }_{5}$ Nichols v. Universal Pictures Corp., 45 F.2d 119, 121 (2d Cir. 1930). 
"ordinary" or "plain" meaning of the words of a patent claim, ${ }^{6}$ there may simply be no such thing. If so, recognizing the problem won't necessarily help us to solve it. In that case, perhaps it is time to reconsider our 130-year commitment to the idea that claims accurately define the outer bounds of the scope of the invention. Particle physicists long ago recognized that the wave packets they studied had no sharply delineated outer contours or boundary, but rather existed as a range of probable energy levels. Such particles are defined by the core region where they are most likely to be found, not by a sharp perimeter beyond which they will never be found. The text of patent claims may have similar properties, lacking a sharp outer perimeter, but usually situated within a particular core range of meaning. If we can't define the "metes and bounds" of the invention in any meaningful way, we might instead start with the patentee's invention itself, construing patent claims narrowly and in light of the actual invention when the claim terms are ambiguous. Courts could then supplement this narrower claim construction with a doctrine of equivalents analysis, which would permit them to decide how broadly to apply the principle of the invention. At a minimum, construing ambiguous claim language narrowly while reinvigorating the doctrine of equivalents would force the courts to pay attention to the issues that really matter-the relationship between the patentee's invention and the accused device-rather than being caught up in semantics.

\section{LEVELS OF ABSTRACTION IN CLAIM CONSTRUCTION}

Claim construction canonically begins with consideration of so-called "literal" infringement, examining the text of the patent claims to determine if they "read on" or correspond to the structures of an accused device." The classic formulation of literal infringement requires that every element of the claimed invention must be found in the accused device. ${ }^{8}$ If literal infringement is found, the alleged infringer can at least theoretically escape liability by showing under the reverse doctrine of equivalents that although every element is present, they combine to produce a result not contemplated in the claimed invention. ${ }^{9}$ If in either case no literal infringement is found, the court may move to consider under the doctrine of equivalents whether one or more of the elements of the claimed invention has been replaced by a substitute that is substantially the same as the element in the claimed invention. ${ }^{10}$

6 See, e.g., Kirin-Amgen, Inc. v. Hoechst Marion Roussel, Ltd., [2004] UKHL 46 para. 34 ("And for [the purpose of claim construction], the language he has chosen is usually of critical importance. The conventions of word meaning and syntax enable us to express our meanings with great accuracy and subtlety and the skilled man will ordinarily assume that the patentee has chosen his language accordingly.").

7 Autogiro Co. of Am. v. United States, 384 F.2d 391, 399 (Ct. Cl. 1967).

8 See, e.g., Robert Patrick Merges \& John Fitzgerald Duffy, Patent Law and POLICY: CASES AND MATERIALS 882 (3d ed. 2002).

9 Scripps Clinic \& Research Found. v. Genentech, Inc., 927 F.2d 1565, 1581 (Fed. Cir. $1991)$.

10 Autogiro Co. of Am., 384 F.2d at 399-400. 
In any of these stages, some meaning must be assigned to the written claims. A variety of interpretive techniques have been developed over the years in order to determine the meaning of claims, including examination of the patent specification and the prosecution history of the patent. But the Federal Circuit has held on a number of occasions that, absent some necessary reason to do otherwise, claim terminology will be given its "plain" or "ordinary" meaning, and that the plain meaning of the claims is preferably determined without reference to "extrinsic evidence" outside the patent itself and its prosecution history. ${ }^{11}$ Paradoxically, the court has also not merely approved, but actually encouraged the consultation of dictionaries, an extrinsic source, to determine the "plain meaning" of terms found in patent claims. ${ }^{12}$

Whatever guidance is used to reach a particular meaning for claims, the act of interpretation will of necessity create two classes: one constituted of items falling within the given meaning and one constituted of items falling outside of it. ${ }^{13}$ But the division between inclusion and exclusion is only the beginning of the story. Any given term will be susceptible of a range of potential meanings that create narrower or broader classifications.

Such classification is well illustrated in decisions such as Unique Concepts, Inc. v. Brown, ${ }^{14}$ where the Federal Circuit considered the infringement of a patent for a border piece framework used for attaching fabric wall coverings to a wall. The claims of the patent were drawn to a framework assembly "comprising linear border pieces and right angle corner border pieces." 15 The defendant argued that the accused device did not infringe because it did not employ pre-formed right angle corner pieces, but rather linear pieces with 45 degree mitered ends that could be formed into a right angle corner piece. ${ }^{16}$ The majority held that the accused device escaped infringement because the mitered linear pieces were not "right angle corner border pieces." 17 Linear pieces and corner pieces, the majority reasoned, constituted separate elements of the claim, and considering mitered linear elements to be corner pieces would render the recitation of linear elements superfluous. ${ }^{18}$ But Judge Rich, in dissent, argued that right angle corner border pieces included mitered linear pieces as well as pre-formed corner pieces, as these were each essentially a sub-class of the "right angle corner border" piece. $^{19}$

Despite reaching conflicting results, both the majority and the dissent claimed with some justification to have given the term its "clear meaning." The

11 See, e.g., Vitronics Corp. v. Conceptronic, Inc., 90 F.3d 1576, 1584-85 (Fed. Cir. 1996).

12 Texas Digital Sys., Inc. v. Telegenix, Inc., 308 F.3d 1193, 1202, 1205 (Fed. Cir. 2002).

13 MERGes \& DufFY, supra note 8, at 908.

14939 F.2d 1558 (Fed. Cir. 1991).

15 Id. at 1561 .

$16 I d$.

17 Id.

18 Id. at 1562.

19 Id. at 1567-68 (Rich, J., dissenting). 
interpretive difference stems from a disagreement over the breadth of category assigned to the disputed term in the claims. Both the majority and dissent carved out the term "right angle corner border pieces" as the relevant unit of text for comparison with the mitered border pieces of the accused device. ${ }^{20}$ But the majority gave this element a constrained reading, limiting it to pre-formed L-shaped pieces, whereas the dissent gave the text a less determinate reading, expanding it to include both pre-formed and assembled corners pieces. ${ }^{21}$

Although claim interpretation is fundamental to patent law, both the theory and doctrine of the practice remain astonishingly underdeveloped, limited mostly to squabbles over the proper or improper application of "ordinary meaning." But this problem of interpreting text to a greater or lesser degree of inclusion has been explicitly dealt with in another area of intellectual property law: that of copyright.

Copyright infringement, like patent infringement, requires the comparison of the proprietary work with an allegedly infringing item. Unlike patents, however, copyright law prohibits only copying, not independent development of a similar work. This means that comparison of the similarities between the proprietary and allegedly infringing works is not enough. Those similarities may be happenstance or dictated by other non-infringing considerations. Access to the infringing work must also be proven, and similarities between the protected and accused works may be taken as circumstantial evidence of copying, a complication not present in the patent infringement analysis. At the same time, under copyright, even the copying of proprietary work is excused when unprotected portions of the work have been taken. Thus, in assessing potential copyright infringement, the possibility of permissible copying of unprotected aspects of the work makes necessary the separation of protected from unprotected. Only copied, protected aspects of the proprietary work need be considered when analyzing possible infringement. In particular, these limits on copyright protection dictate the separation of idea from expression. Copyright protects only the original expression in a work, while the idea behind the expression is freely available for copying. ${ }^{22}$

This rule rests on the assumption that there are typically many different ways to express a particular idea or creative motif. For example, anyone who wishes may take the general theme or concepts of West Side Story and create their own dramatic production about the tragic story of lovers from opposing clans, whose animosity keeps them apart and eventually leads to their deaths. A copyist who takes only such a general outline or concept of a work is not considered to have taken anything protected. But as the copyist begins to take more specific, detailed expression, expression considered original to its author, then copyright is infringed.

But this ostensibly simple theory of infringement cloaks the difficult problem of how to determine when a copyist has crossed the line from appropriation of unprotected ideas to appropriation of protected expression.

20 Id. at $1561,1568$.

21 Id. at 1568 .

22 Baker v. Selden, 101 U.S. 99 (1879). 
Methodologically, this approach to infringement requires some process for separating expression from idea. Courts have developed such a process in the so-called "levels of abstraction" test. The classic formulation of this method originates with Judge Learned Hand's opinion in Nichols v. Universal Pictures Corp.: $:^{23}$

Upon any work ... a great number of patterns of increasing generality will fit equally well, as more and more of the incident is left out. The last may perhaps be no more than the most general statement of what the [work] is about, and at times may consist only of its title; but there is a point in this series of abstractions where they are no longer protected, since otherwise the [author] could prevent the use of his "ideas"... .

This levels of abstraction test is in many senses an exercise in hierarchical category sorting, or in levels of classification comparison: are the works compared merely distant cousins, sharing only a classification in the same broad category of, for example, love stories? Or do they share a narrower subclassification, for example "Romeo and Juliet" love stories? Placing the works within such a broad categorical space indicates that they have only the unprotected "idea" of the story in common. But if they share a sufficiently narrow sub-sub-classification, for example, where the characters or plot complications share specific details, or where the narrative shares the same wording, then we conclude that expression, and not merely ideas, overlap. Absent independent development, placement within a sufficiently narrow categorical space indicates that infringement has occurred.

In Nichols, Judge Hand applied the test to examine the infringement of a stage play by a motion picture, comparing the protected expression in plot development and character attributes. ${ }^{25}$ Although Judge Hand developed levels of abstraction analysis in the setting of infringing dramatic works, in theory the test might be applied to assess infringement for any type of copyrightable subject matter, comparing the protected and unprotected expression between original and accused literary works or musical compositions or graphic arts. The test might in theory equally well be applied across subject matters, assessing potential infringement of a painting by an accused sculpture, or potential infringement of a novel by a musical composition.

In recent years, the levels of abstraction methodology has had its greatest prominence in cases involving computer software, examining infringement at different levels of software composition, from the literal copying of code to copying of the "structure, sequence, and organization" (SSO) of programs. ${ }^{26}$ It is perhaps not surprising that the levels of abstraction test has found such application in the analysis of computer software infringement. Levels of abstraction analysis was developed in the context of literary and dramatic works, and due to their symbolic nature, computer programs are classified as

2345 F.2d 119 (2d Cir. 1930).

${ }^{24} I d$. at 121.

25 Id.

26 See Computer Assocs. Int'l, Inc., v. Altai, Inc., 982 F.2d 693, 703 (2d Cir. 1992). 
"literary works" under the subject matter of copyright. ${ }^{27}$ Literary works will tend to share an ordinal structure, a sequential arrangement of symbols in linear fashion with comparable organization at differing levels of structure that might be labeled plot, storyline, or SSO. Levels of abstraction may indeed be best suited to a linear text-to-text comparison, and less suited to comparing different categories of works. Identifying commonalities between differing types of subject matter inherently requires resort to a greater degree of generality. As a consequence, comparisons across subject matter must always proceed at higher levels of abstraction. Dialogue from a dramatic work might literally be found in a motion picture, but the visual depiction of television characters is nowhere to be found in a quiz book about their show's trivia.

This problem of comparing apples to oranges is even more apparent in patent law, as claim interpretation virtually always constitutes a mapping of a text - the claims - onto a physical object-the accused device. ${ }^{28}$ The interpreter of claims must decide not only how broadly to view a given element in the text of the claims, but how to view or classify a corresponding structure in the accused device-indeed, to identify what portion of the claimed device corresponds to an element of the claims. ${ }^{29}$ Thus, even so-called literal claim interpretation occurs at a relatively high level of abstraction, as no text is "literally" found in the claimed invention-only a correspondingly described physical structure.

The levels of abstraction methodology can be discerned within patent law by considering a simple example of claim construction, as illustrated in Table 1 , where the claim recites "a screw" as an element of the claimed invention. Here the language of the claim lends itself to a comparatively low level of abstraction, limited to a particular type or category of hardware. Under a "plain meaning" approach to this element, the most common or "default" reading of the text maps to this type of hardware, and it is this "default" type of hardware- "a screw"- that will have to be present as a structure in the accused device for the claim to read upon the accused device.

Of course, even within this limited reading, there may be considerable latitude for sub-categorization, as the term "screw" might encompass a variety of sub-types: wood screws, sheet metal screws, threaded bolts, and other similar types of hardware. But attempting to read this text beyond a very constrained level of abstraction risks either invalidating the claim, as the

27 See H.R. REP. No. 94-1476, at 54 (1976), reprinted in 1976 U.S.C.C.A.N. 5659, 5667.

28 While the Federal Circuit has spoken of literal infringement occurring when the accused device reads "word-for-word" on the patent claim, see SRI Int'l v. Matsushita Elec. Corp. of Am., 775 F.2d 1107, 1118 (Fed. Cir. 1985) (en banc), they were of course speaking metaphorically. There are no words in the accused device to map to the words of the claim.

29 A similar problem arises in so-called "means plus function" claims when the scope of the claim is limited to the structure disclosed in the specification plus equivalents thereof. Courts have struggled with deciding how to map the text of the claims onto the structures described in the language of the specification. See David C. Bohrer \& Michael I. Frankel, The Question Left Unanswered in WMS Gaming: What is the Algorithm?, $16 \mathrm{~J}$. PROPRIETARY RTS. 8, 8 (2004) (identifying WMS Gaming, Inc. v. Int'l Game Tech., 184 F.3d 1339 (Fed. Cir. 1999), as an example of this problem). 
ballooning scope of "screw" exceeds the disclosure and impinges upon prior art, or throwing the interpretation into the realm of the doctrine of equivalents, where the words of the claim are made to "cover more than their meaning will bear. $" 30$

Table 1

\begin{tabular}{|l|l|l|l|}
\hline $\begin{array}{l}\text { Legal } \\
\text { Doctrine }\end{array}$ & $\begin{array}{l}\text { Claims } \\
\text { Recite }\end{array}$ & $\begin{array}{l}\text { Claims Construed to } \\
\text { Cover }\end{array}$ & Accused Structure \\
\hline \hline $\begin{array}{l}\text { Narrow } \\
\text { construction }\end{array}$ & "a screw" & $\begin{array}{l}\text { a wood screw (the } \\
\text { screw disclosed in } \\
\text { the specification) }\end{array}$ & a wood screw \\
\hline $\begin{array}{l}\text { Broad } \\
\text { construction }\end{array}$ & "a fastener" & $\begin{array}{l}\text { any type of means } \\
\text { for attaching }\end{array}$ & a nail \\
\hline $\begin{array}{l}\text { Doctrine of } \\
\text { Equivalents }\end{array}$ & "a screw" & "a fastening device" & a nail \\
\hline $\begin{array}{l}\text { Reverse } \\
\text { Doctrine of } \\
\text { Equivalents }\end{array}$ & "a screw" & $\begin{array}{l}\text { a screw (performing } \\
\text { the function of } \\
\text { fastening Part A to } \\
\text { Part B) }\end{array}$ & $\begin{array}{l}\text { a screw (performing } \\
\text { the function of } \\
\text { separating Part A from } \\
\text { Part B) }\end{array}$ \\
\hline
\end{tabular}

As next summarized in Table 1, a broader category might be encompassed by an alternative claim to "a fastener." In this instance, a higher level of abstraction is indicated, even required, by the "plain meaning" of the text of the claim itself. Here the claim itself uses language in which the plain meaning "default" is set at a higher level of abstraction; the constituent parts of the claimed invention might be fastened by screws, nails, glue, Velcro, or a variety other fastening agencies. The structural element identified in the accused device, a nail, falls into this broad category of fastening agencies. But this classification of the accused structure in turn means that we are viewing the structure, the nail, itself as a more abstract category-not simply as a nail, but as a "fastener," and one of the category of things that may fasten components of the device together. Thus the accused device, as well as the text of the claim, may be viewed at different levels of abstraction.

In a third variation on the example, we return to the text of the claim first considered-reciting as an element, "a screw." But here, the analogous structure found in the accused device is a nail, a piece of hardware falling outside the range of hardware indicated by the "default" meaning of the claim language. Nonetheless, a court might determine that the nail is a trivial substitution for a screw in the accused device, and that the claims should read on the accused device by virtue of the doctrine of equivalents. The doctrine of equivalents effectively treats the element "a screw" as a broader or more abstract category of hardware, "fastening device," including both nails and screws, performing the function of fastening.

30 Royal Typewriter Co. v. Remington Rand, Inc., 168 F.2d 691, 692 (2d Cir. 1948) (L. Hand, J.). 
Paragraph six of 35 U.S.C. $\S 112$ explicitly permits the claiming of structures by designating their function, referencing such functional structures disclosed in the specification "and equivalents thereof." function" claim elements partake in the same range of abstraction as the doctrine of equivalents; indeed, they are specifically written to encompass more general categories of structure, grouped by function. In determining the degree of generality to be accorded such claims, the court may be required to explicitly choose between equivalently disclosed terminology at different levels of abstraction. Thus, in Chiuminatta Concrete Concepts, Inc. v. Cardinal Industries, Inc. ${ }^{32}$ which involved a means-plus-function claim element providing support for a concrete saw, the court read the specification and chose among terms found there the narrower "skid plate," rather than the broader "support surface," as the right level of abstraction for analysis of the claims. ${ }^{33}$ Both terms were used in the specification, and the court was required to make a choice of whether to choose the more specific or the more general term in construing the claims. ${ }^{34}$

This makes clear that, as in the case of literal infringement, equivalents may cover a range of levels of abstraction. ${ }^{35}$ The range of levels available within an equivalents inquiry is closely tied to the degree of abstraction accorded the "function," "way," and "result" components of the tripartite test. Differing levels of abstraction can be seen, for example, in the Federal Circuit's doctrine of equivalents analysis in Overhead Door Corp. v. Chamberlain Group, Inc. ${ }^{36}$ There, the Federal Circuit held that a reasonable jury could find that a claimed garage door opener that employed a mechanical switch was equivalent to an accused device that employed an electronic switch implemented in software. ${ }^{37}$ This result followed from the court's implicit decision to interpret the switch element at a high level of abstraction-that is, to adopt the view that the "way" in which both the mechanical and software switches functioned was by turning the device on or off. ${ }^{38}$ By contrast, an analysis at a lower level of abstraction, one that inquired into how the claimed and accused switches actually worked, would likely have found substantial differences between a physical lever and a computer program.

This suggests that, far from being an altogether separate exercise from literal infringement, the doctrine of equivalents simply designates the farther end of a range of abstraction. While literal reading of the claims incorporates a range of abstractions at the lower level, the doctrine of equivalents covers a range of abstractions at the higher level. This is well-illustrated in what one might call the "oppositional" cases, in which the court regularly concludes that

3135 U.S.C. $\$ 112$, para. $6(2000)$.

32145 F.3d 1303 (Fed. Cir. 1998).

33 Id. at 1308.

34 Id.

${ }^{35}$ See Julie E. Cohen \& Mark A. Lemley, Patent Scope and Innovation in the Software Industry, 89 CAL. L. Rev. 1, 50 (2001).

36194 F.3d 1261 (Fed. Cir. 1999).

37 Id. at 1270.

38 Id. 
a claim term selecting one part of a duality cannot be read to encompass the other part, either literally or under the doctrine of equivalents. For example, in Moore U.S.A., Inc. v. Standard Register Co., ${ }^{39}$ the court held that a claim that required that a particular element extend for a "majority" of the length of the product was not infringed by an accused device in which the element extended only $47.8 \%$ of the length, because "it would defy logic to conclude that a minority-the very antithesis of a majority-could be insubstantially different from a claim limitation requiring a majority, and no reasonable juror could find otherwise. ${ }^{40}$ But this is merely a function of the level of abstraction of the claim, which has created an artificial duality. Redraft the claim to require that the length be "at least $50 \%$ " of the total, and it seems quite plausible that the courts would find a compound with $48 \%$ of the length to infringe under the doctrine of equivalents. Indeed, Judge Newman, dissenting, thought this very question a disputed issue of fact that could not be decided on summary judgment. ${ }^{41}$

Adopting the terminology of copyright, a range of abstraction in the doctrine of equivalents lies very close to the "idea" of the claim. In the doctrine of equivalents range of abstraction, the court treats the "default" meaning of the claim words as representative, or illustrative, of the broader class of elements unstated in the text. ${ }^{42} \mathrm{~A}$ similar process of abstraction occurs with regard to reverse equivalents. Seldom invoked, the doctrine of reverse equivalents stands as a defense to literal infringement, not to infringement by equivalents. ${ }^{43}$ Under this defense, an accused device that falls literally within the scope of the claims may be found not to infringe if it is so far changed in principle as to perform a different function or act in a different way or reach a different result than the claimed invention. ${ }^{44}$ The doctrine owes its origins to the equitable impulse that if imprecision in language sometimes redounds to the benefit of the patentee, it may also sometimes redound to the benefit of the alleged infringer. If the patentee is sometimes entitled to more than stated in the exact language of his claims, sometimes he may be entitled to less. ${ }^{45}$

A final iteration of this Table 1 example invokes this doctrine of reverse equivalents. Here, the claims recite "a screw," and the accused device includes in its structure a screw situated in the manner dictated by the claims. However, examination of the accused device reveals that the screw serves to separate or hold apart two components of the device, whereas in the claimed invention the screw serves to fasten them together. Even though the two structures are the same, the operation of the screw in the accused device so far changed in principle that it is in fact a different invention, and escapes infringement despite literally reading on the claims. In essence, the text of the claims is viewed as

\footnotetext{
39229 F.3d 1091 (Fed. Cir. 2000).

40 Id. at 1106 .

41 Id. at 1119-20 (Newman, J., dissenting).

42 Autogiro Co. of Am. v. United States, 384 F.2d 391, 399-400 (Ct. Cl. 1967).

43 Pennwalt Corp. v. Durand-Wayland, Inc., 833 F.2d 931, 962 (Fed. Cir. 1987).

44 Id.

45 See Graver Tank \& Mfg. Co. v. Linde Air Prods. Co., 339 U.S. 605, 608-09 (1950)
} 
reciting a "fastening screw" whereas the accused device is viewed as containing a "separating screw."

Because it comprises a gloss on the literal scope of the claims, a reverse equivalents analysis technically parses the claims at a low level of abstraction. Under reverse equivalents, an element such as a "screw" is nominally limited to the narrow category of hardware attributed to it under literal infringement. But at the same time, the function of the accused device is clearly taken as more than the sum of its parts, driving the analysis toward a higher level of abstraction. For example, in the classic statement of reverse equivalents found in Westinghouse v. Boyden Power Brake Co. ${ }^{46}$ the Supreme Court compared a patented railroad air brake to an allegedly infringing brake, finding that every element of the claimed invention was present in the accused device. ${ }^{47}$ But the Court held that the accused brake was performing a different function in a different way to reach a different result. ${ }^{48}$ Specifically, although both the recitations of the claims and the structure of the accused device included a release valve, the Court found that the release valve in the accused device served an entirely different function in operation of the brake. In this analysis, the valve in the accused device is viewed as something more than a valve; indeed the Court dubs it an "auxiliary valve" or an "independent valve" to designate its difference in function. ${ }^{49}$ Consequently, when the accused element is viewed at a higher level of abstraction - the purpose or function of devices of this class - the Court finds it to constitute an entirely new invention, even though the particular valve in question is said to read on the element described in the claim. ${ }^{50}$

This situation to some extent tracks that of abstraction under a doctrine of equivalents analysis. As in the doctrine of equivalents, the analysis at a higher level of abstraction follows an analysis at the lower level of abstraction appropriate to literal claim interpretation. And as in the doctrine of equivalents, the choice of a higher level of abstraction is largely driven by the nature of the accused device. But not surprisingly, given its name, reverse equivalents reverses or inverts the process, mapping the claims onto a relatively highly abstracted accused device after that device has been found to infringe at the lower, literal level of abstraction.

More generally, it should be clear from this discussion that one cannot simply pick "the" plain meaning of any given term. Terms not only can have different meanings, but they can have a range of meanings, from narrow to broad, and the hierarchy of interpretive doctrines - from literal interpretation to equivalents to reverse equivalents-is merely a shorthand for the level of abstraction chosen for the textual meaning. The level of abstraction at which the term is defined will significantly affect the scope of the claim.

$46 \quad 170$ U.S. 537 (1898).
47 Id.
48 Id. at $572-73$.
49
Id. at $571-72$.
$50 \quad I d$.




\section{THE SIZE OF ELEMENTS}

Implicit in our discussion to this point has been a second, related phenomenon, besides the choice of abstraction-the choice of what "chunk" or quantum of text to consider in assigning a level of abstraction. Choosing the quantum to be measured is important for patent litigation. The role of an "element" (or "limitation") 51 is critical in patent infringement analysis. A defendant does not literally infringe a patent unless each and every element is present in the accused device. ${ }^{52}$ Nor can the patentee escape the role of the element by relying on the doctrine of equivalents. While courts once used the doctrine as a means to promote equity by preventing infringers from making any insubstantial change to a patented invention, ${ }^{53}$ that is no longer true. The doctrine of equivalents too has been tested on an "element-by-element" basis since $1987 .{ }^{54}$ The proper scope of an element is also relevant to patent validity, since a patent is anticipated under 35 U.S.C. $\S 102$ only if every element of the claimed invention is contained in a single prior art reference. ${ }^{55}$ Elements also affect inventorship. An individual who works on a project is a joint inventor if, but only if, the individual contributes to at least one element of a claim of the patent. 56

Given the large number of instances in which the size of the element matters, it is somewhat surprising that there is no legal standard for deciding what constitutes an element of the invention. ${ }^{57}$ Courts have in the past defined an element to be as small as a single word and as large as the entire claim.

Perhaps the most striking example of the latter interpretive endpoint is found in the Federal Circuit opinion in Corning Glass Works v. Sumitomo Electric U.S.A., Inc., ${ }^{58}$ where the court applied a doctrine of equivalents analysis to a fiber optic waveguide patent. The claims were drawn to an optical

51 The Federal Circuit said en banc in Festo Corp. v. Shoketsu Kinzoku Kogyo Kabushiki Co. that "[i]t is preferable to use the term 'limitation' when referring to claim language and the term 'element,' when referring to the accused device." 234 F.3d 558, 564 n.1 (Fed. Cir. 2000). But this approach has not been widely adopted, even by the Federal Circuit.

52 See, e.g., MERGES \& DuFFy, supra note 8 , at 882.

53 See, e.g., Martin v. Barber, 755 F.2d 1564, 1568 (Fed. Cir. 1985); Carman Indus., Inc. v. Wahl, 724 F.2d 932, 942 (Fed. Cir. 1983); Hughes Aircraft Co. v. United States, 717 F.2d 1351 (Fed. Cir. 1983).

54 Pennwalt Corp. v. Durand-Wayland, Inc., 833 F.2d 931, 935 (Fed. Cir. 1987) (en banc). The Supreme Court reaffirmed this approach in Warner-Jenkinson Co. v. Hilton Davis Chem. Co., 520 U.S. 17 (1997).

55 See, e.g., Scaltech Inc. v. Retec/Tetra, L.L.C., 178 F.3d 1378, 1384 (Fed. Cir. 1999).

56 See, e.g., Ethicon, Inc. v. U.S. Surgical Corp., 135 F.3d 1456, 1463 (Fed. Cir. 1998); Winbond Elec. Corp. v. Int'l Trade Comm'n, 262 F.3d 1363, 1372 (Fed. Cir. 2001).

57 See Matthew C. Phillips, Taking a Step Beyond Maxwell to Tame the Doctrine of Equivalents, 11 Fordham InTEll. Prop. Media \& ENT. L.J. 155, 162 (2000) ("The definition of an 'element' is slippery and probably cannot be settled without some resort to arbitrariness. Presently, an element seems to be more than just a single word, but potentially less than an entire step in a method or an entire constituent part of an apparatus (as is typically demarcated by semicolons).").

58868 F.2d 1251 (Fed. Cir. 1989). 
fiber comprised of a silica core "doped" with an impurity, surrounded by cladding of pure silica. ${ }^{59}$ The dopant in the core of the claimed fiber raised the index of refraction ("RI") of the core in relation to the cladding, creating an RI differential to guide light down the fiber and prevent it from scattering. ${ }^{60}$ The accused device comprised a pure silica core surrounded by a silica cladding that had been "doped" with a different kind of impurity that lowered the RI of the cladding in relation to the core. ${ }^{61}$ Thus, both the claimed invention and the accused device functioned by raising the RI of the core in relation to the cladding, but the claimed invention did so by adding a positive dopant to the core, whereas the accused device did so by adding a negative dopant to the cladding. ${ }^{62}$

Since the accused device lacked the positively doped core recited in the claims, there could be no question of literal infringement, and the case turned on the question of equivalence. ${ }^{63}$ The plaintiff argued that the accused fiber performed substantially the same function in substantially the same way to achieve substantially the same result as the claimed fiber. ${ }^{64}$ But even under the doctrine of equivalents, infringement still requires that every element of the claims be found in the accused device, literally or by equivalents. Where was the element of a doped core to be found? The court answered the question of the missing element by essentially reading the entire claim a single element, equivalent to the entire accused device. ${ }^{65}$ Since both used dopants to create an RI differential between the core and the cladding, the equivalent of the claimed invention was found to be present in the accused device. ${ }^{66}$ This reading of the claim takes the very largest chunk of text possible - the entire claim-as the quantum for claim interpretation.

While Corning Glass Works shows the malleability of the element-byelement approach, the decision is arguably more properly understood as a rejection of that approach altogether in favor of the discredited application of the doctrine of equivalents as a whole. Nonetheless, even courts that clearly apply the element-by-element test sometimes define that element in very broad terms. For example, in Hughes Aircraft Co. v. United States, ${ }^{67}$ the patent covered a method for reorienting a satellite in orbit. Several of the steps involved the communication of telemetry data from the satellite to a ground control computer, the calculation of the appropriate correction on the ground, and the transmission of instructions from ground control to the satellite. ${ }^{68}$ Because of ongoing progress in computer technology, the defendant was able to conduct the same calculations on board the satellite with the help of a

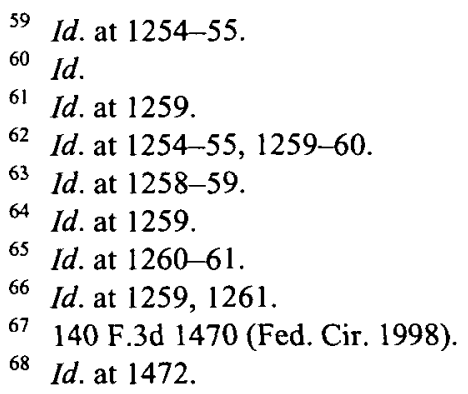


microprocessor. ${ }^{69}$ Nonetheless, the Federal Circuit found that the defendant's satellite infringed the patent under the doctrine of equivalents. ${ }^{70}$ In doing so, the court had to decide whether a single on-board device that performed those multiple functions could itself be equivalent to the many devices used in the patent. The court ultimately found that it could. But its definition of those functions is interesting. It found the language

(e) means disposed on said body for providing an indication to a location external to said body of the instantaneous spin angle position of said body about said axis with reference to a fixed external coordinate system;

(f) and means disposed on said body for receiving from said location control signals synchronized with said indication;

(g) said valve being coupled to said last-named means and responsive to said control signals for applying fluid to said fluid expulsion means in synchronism therewith for precessing said body to orient said axis into a predetermined desired relationship with said fixed external coordinate system $^{71}$

to effectively constitute only two elements in the patent, and concluded that the equivalent functions and processes of all of these words were performed by a single on-board microprocessor in the accused device. ${ }^{72}$ Had the court treated each word as a separate element requiring an equivalent, it is doubtful it would have found infringement.

At the same time, other decisions have read the definition of an element much more narrowly. Warner-Jenkinson Co. v. Hilton Davis Chemical Co., ${ }^{73}$ for example, involved a patent on an ultrafiltration process for purifying dye. During prosecution, the patentee added to the claims the requirement that the process occur "at a pH of approximately 6.0 to $9.0 ., 74$ The question before the Court was whether prosecution history estoppel barred the patentee from arguing that 5.0 was equivalent to $6.0 .^{15}$ The Court analyzed the question by assuming that the amendment had added not one, but two different elements: a "less than 9.0" limitation and a "greater than 6.0" limitation. ${ }^{76}$ It explored the reason for each change separately and, when it could find no reason for the "greater than 6.0" limitation, applied a rebuttable presumption that it was added for a reason related to patentability, triggering prosecution history estoppel. ${ }^{77}$ The Court's assumption, that a single change in the language of the claim introduced two distinct new elements, treated the concept of an element as very small and led it to limit the scope of the patent. ${ }^{78}$ By contrast, had the Court

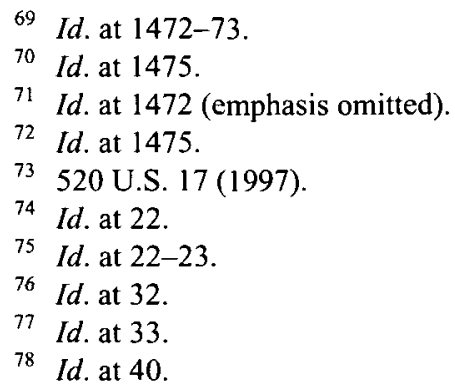


treated the added phrase "at a $\mathrm{pH}$ of approximately 6.0 to 9.0 " as a single element, if would have concluded that the reason for that change was to address prior art that operated at a $\mathrm{pH}$ of 10 , and might not have barred application of the doctrine of equivalents to processes that worked at a $\mathrm{pH}$ of 5 .

Other courts have construed quanta even more narrowly, finding that a single word can constitute an "element" whose absence dooms assertions both of literal infringement and infringement under the doctrine of equivalents. For example, in Larami Corp. v. Amron, ${ }^{79}$ the patent covered a water gun with a piston used to compress air so that the gun could shoot water further. The claim at issue in the case required that the barrel of the gun have "a chamber therein for a liquid.. ${ }^{\prime 80}$ The defendant's product did not house the water inside the gun barrel, but in a separate reservoir attached to the top of the barrel..$^{81}$ The court concluded that the defendant's product did not meet the "therein" limitation, and therefore did not infringe the patent either literally or under the doctrine of equivalents, even though the rest of the phrase ("a chamber . . . for a liquid") was clearly present in the accused device. ${ }^{82}$ In so doing, the court effectively defined the element as covering only a single word. Similarly, the court in Kustom Signals v. Applied Concepts decided that the word "or" standing alone was an element. ${ }^{83}$

It should be obvious that the choice of quantum can determine the outcome of cases. Hughes Aircraft would have come out very differently if the patentee had been required to show a corresponding equivalent for each word in the claim describing the telemetry its on-board microprocessor replaced. Similarly, if the Warner-Jenkinson Court had viewed the phrase "at a pH of from approximately 6.0. to 9.0 " as a single element, it would have understood why that element was added and need never have relied on a presumption of prosecution history estoppel. ${ }^{84}$ But the choice of quantum can also affect the meaning of terms within the quantum. In Texas Digital Systems, Inc. $v$. Telegenix, Inc. ${ }^{85}$ for instance, the patent claim covered a process that involved "repeatedly substantially simultaneously activating" two lights. ${ }^{86}$ The district court construed this phrase as a whole to mean that the two lights must be on at about the same time on more than one occasion. ${ }^{87}$ The Federal Circuit, by contrast, broke the claim up differently, looked the term "activating" up in a dictionary, and concluded that it was the act of turning the light on, that must occur at the same time, not simply that the lights must be on at the same time. ${ }^{88}$ The Federal Circuit's understanding of the term "activating" makes sense standing alone, but when the phrase is read as a whole the case is a closer one.

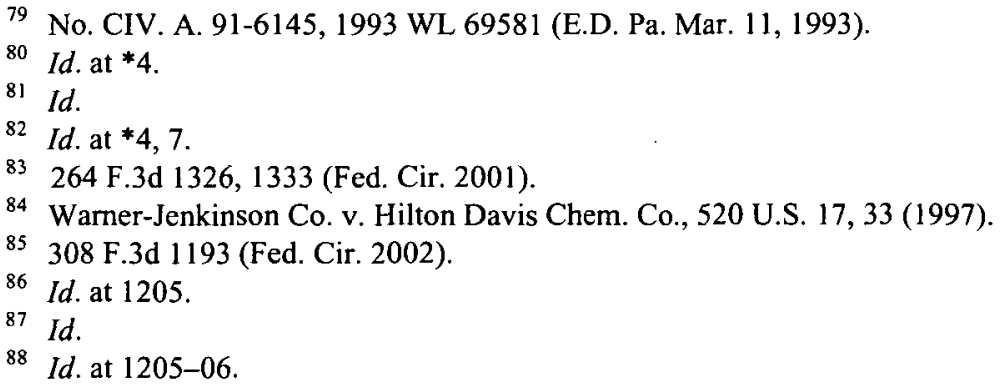


This is just one example of how the choice of quanta can affect not just what the parties have to prove, but the very meaning of the terms within the quantum themselves.

None of the cases we have discussed expressly considered the proper size of an element. Rather, they simply assumed that the word or phrase they considered was the right one, even though this assumption drove their conclusion in each case. The closest the court came to treating the issue was in Corning Glass Works, where it said:

"Element" may be used to mean a single limitation, but it has also been used to mean a series of limitations which, taken together, make up a component of the claimed invention. In the All Elements rule, "element" is used in the sense of a limitation of a claim. ${ }^{89}$

While this sounds like helpful guidance, it is important to remember that the panel that wrote this language effectively treated the entire claim before it as a single element. So it is not clear how seriously we are meant to take the admonition that elements are narrow and do not aggregate a series of limitations.

Occasionally, courts do confront the question of the proper quantum size directly. For example, in Ericsson, Inc. v. Harris Corp.,${ }^{90}$ the patent claimed a cordless telephone handset that used power stored in the speech signal amplifiers when the phone was off the hook. The claims required that the phone "only supply power" from speech signal amplifiers when the handset is off the cradle. ${ }^{91}$ The defendant's phone primarily supplied power to the phone from an external source when it was on the cradle, but also drew on the speech signal amplifiers to power the phone even when it was on the cradle. ${ }^{92}$ The patentee had amended the general part of the claim of which this language was a part, but not the particular language in question. ${ }^{93}$ The issue was whether the doctrine of prosecution history estoppel prevented application of the doctrine of equivalents to cover a phone that primarily but not only supplied power as specified in the patent. ${ }^{94}$ The majority held that the doctrine of prosecution history estoppel did not apply because the three particular words in question were not themselves amended. ${ }^{95}$ Thus, the court effectively defined the element in question as those three words.

Judge Newman, dissenting, argued that the element was the broader phrase of which the words "only supplies power" were a part. Because that broader phrase was amended, Judge Newman would have applied the doctrine of prosecution history estoppel to the broader element she perceived. ${ }^{96}$ Even in

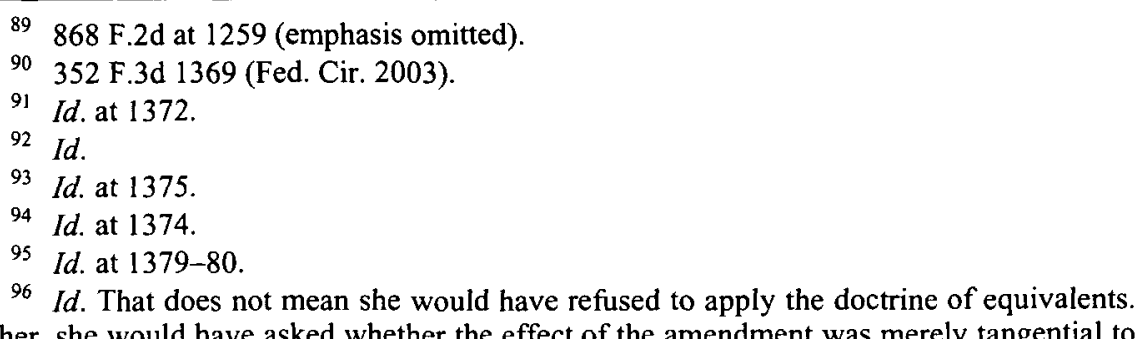

Rather, she would have asked whether the effect of the amendment was merely tangential to 
Ericsson, where the outcome turned on the definition of the element, the court did not offer any guidance for choosing the right quantum. Moreover, the fact that the panel disagreed on its premises - and hence on the outcome-without offering any standards for determining the right answer does not bode well for future analyses of the question.

While the question is not generally discussed, and no express standards have been set, recent trends may be pushing towards smaller quanta. The focus of the courts in the last seven years on claim construction as a matter of law, and in particular the more recent emphasis on dictionary definitions of terms, necessarily focuses the analysis on either a single word or at most a short phrase. No dictionary, technical or lay, includes fifty-word phrases in its entries. As a result, the size of an element in anticipation and literal infringement cases today tends to be a much smaller piece of the overall patent claim than was true two decades ago. ${ }^{98}$ While this is not necessarily binding in a doctrine of equivalents analysis, where dictionaries do not generally play a role, the natural tendency of courts is to identify the elements for which literal infringement is lacking as the same elements for which it construed the claims. This is particularly true since courts must instruct juries on the meaning of particular claims and, in the case of prosecution history estoppel, instruct them not to apply the doctrine of equivalents to a particular element. Focusing on individual words and short phrases in claim construction therefore inclines the courts to do so in structuring the doctrine of equivalents inquiry as well.

\section{THE SEARCH FOR DEFINITE MEANING}

\section{A. How Quanta and Abstractions Affect Patent Decisions}

The two effects we have identified in Parts II and III interact. In the copyright context, courts that can find no substantially similar discrete elements copied from a protected work may nonetheless find infringement based on the

the purpose of the specific limitation in this case, a question mandated by the Supreme Court's decision in Festo. Id. at 1381 (Newman, J., dissenting).

97 See, e.g., Texas Digital Sys., Inc. v. Telegenix, Inc., 308 F.3d 1193, 1202-1203 (Fed. Cir. 2002). The proper role of dictionaries in claim construction is the subject of a pending en banc case at the Federal Circuit. Phillips v. AWH Corp., 376 F.3d 1382 (Fed. Cir. 2004) (setting questions to be considered en banc).

${ }^{98}$ An example-and another example of the quantum of the claim determining the outcome-is Merck \& Co. v. Teva Pharms., 395 F.3d 1364 (Fed. Cir. 2005). There, the majority identified the relevant element as the term "about" and defined it to mean "approximately." Id. at 1369. Judge Rader, dissenting, saw the element to be interpreted as a much broader phrase, and argued persuasively that that whole phrase had been defined in the specification in such a way that the terms "about $70 \mathrm{mg}$." in the phrase meant the amount of a derivative compound that produces exactly $70 \mathrm{mg}$. of the active component. Id. at $1379-$ 80 (Rader, J., dissenting). While there were other issues that divided the majority and the dissent-when a patentee can act as its own lexicographer, and whether deference is appropriate to district court claim constructions-the choice of quantum dictated the approach each took to claim construction, and therefore drove the outcome. See id. at 1369 n.7 (noting the express disagreement over the proper quantum). 
"look and feel" of the work, or in computer software cases on the work's "sequence, structure and organization" (SSO). ${ }^{99}$ In these cases the protected work and the accused work are each viewed and compared to the other as whole, rather than piecemeal as discrete subunits. But this also means that they are compared at a very high level of abstraction, in terms of their general configuration, which is very close to the "idea" of the work.

As we have seen, a very similar process seems to be occurring in patent claim interpretation in a case like Corning Glass Works, where the court essentially views the entire claim as a single element. ${ }^{100}$ But this simultaneously entails reading that element at a very high level of abstraction, to encompass the "idea" of an optical fiber with a refractive index differential between the cladding and the core. ${ }^{101}$ Corning Glass Works thus marks an outer limit, not only of the continuum of claim quantization, but of the intersection of this factor with the continuum of levels of claim element abstraction. The interaction of these two factors, along the length of each continuum, profoundly affects the outcome of both infringement and invalidity decisions.

As we have suggested, assigning a higher level of abstraction to claim elements confers upon them a greater degree of generality, and so a greater scope. Consequently, the selection of a higher abstraction level will tend to benefit patentees in infringement cases as more accused structures will fall within their ambit. At the same time, a higher degree of abstraction may be detrimental to patentees when validity is challenged. More abstract reading of a claim element may in some cases push it toward vagueness, creating the risk that the patent will be invalidated on grounds of claim indefiniteness. ${ }^{102}$ Additionally, higher levels of abstraction will mean a greater degree of generality, increasing the scope of genus claims. If prior art is swept into this increased scope, the patent may fail for anticipation or obviousness or, if the patentee does not justify this broad scope, for failure to enable the use of the claims.

By contrast, the focus on smaller and smaller quanta in recent years will generally redound to the benefit of accused infringers by making it easier to avoid infringement, either accidentally or by means of a design-around. Defining a claim to include many different elements normally limits the scope of patents by permitting even a small change to escape infringement where the accused device has no "equivalent" to a particular word. This practice will not always benefit accused infringers, however. Where anticipation rather than infringement is at issue, treating an element as a small piece will benefit patentees by making it easier for them to distinguish prior art. This result stems from the reciprocal relationship between literal infringement and anticipation. ${ }^{103}$ Even within the infringement sphere, a small-quantum approach

99 Computer Assocs. Int'l, Inc. v. Altai, Inc., 982 F.2d 693, 706 (2d Cir. 1992).

100 Corning Glass Works v. Sumitomo Elec. U.S.A., Inc., 868 F.2d 1251 (Fed. Cir. 1989).

101 Id. at $1258-59$.

10235 U.S.C. $\$ 112(2000)$.

103 See, e.g., SmithKline Beecham Corp. v. Apotex Corp., 365 F.3d 1306, 1315 (Fed. Cir. 2004) ("that which would literally infringe if later in time anticipates if earlier"); Roy $\mathrm{H}$. 
may occasionally have the opposite effect, as where it narrows the application of a limiting doctrine like prosecution history estoppel or the rule against applying the doctrine of equivalents to cover an invention in the prior art. The move towards smaller quanta may even suggest that prosecution history estoppel will not prove as sweeping a limit on the doctrine of equivalents as was first supposed. ${ }^{104}$ And to the extent that the use of small quanta facilitates the role of dictionaries in claim construction, it may actually tend to broaden the claims, since dictionary meanings tend to be broader and less tied to the actual invention than the meanings identified in the specification. ${ }^{105}$ Small quanta, then, tend to push the law towards valid but narrow patents as a general matter, ${ }^{106}$ though there are some aspects of small quanta-notably the role of dictionaries-that push in the opposite direction. ${ }^{107}$

The interaction between abstraction and quanta can be depicted as a $2 \times 2$ matrix in which level of abstraction is a judgment call that determines generality of a term, and quantum is a judgment call that determines how many terms must be matched. Scope is a function of the interaction between the two, as depicted in Table 2.

Table 2

\begin{tabular}{|c|c|c|}
\hline & Large Quanta & Small Quanta \\
\hline High Abstraction & $\begin{array}{l}\text { Very broad patents; } \\
\text { often invalid }\end{array}$ & $\begin{array}{l}\text { Intermediate breadth; } \\
\text { rigid framework but } \\
\text { flexible application } \\
\text { within the framework }\end{array}$ \\
\hline Low Abstraction & $\begin{array}{l}\text { Intermediate breadth; } \\
\text { flexible framework but } \\
\text { high correspondence } \\
\text { required within the } \\
\text { elements that do exist }\end{array}$ & $\begin{array}{l}\text { Very narrow patents; } \\
\text { likely valid }\end{array}$ \\
\hline
\end{tabular}

If a patent is both broken into large chunks and each of those chunks is understood at a high level of generality (box 1), the resulting patent will be

Wepner, The Patent Invalidity/Infringement Parallel: Symmetry or Semantics?, 93 Dick. L. REV. 67, 76, 80-81 (1988); cf. Donald S. Chisum, Anticipation, Enablement, and Obviousness: An Eternal Golden Braid, 15 AIPLA Q.J. 57, 58 (1987). Chisum refers to anticipation and obviousness, but the logic of the braid extends to infringement as well.

104 For example, the court did not apply the doctrine in Ericsson because it concluded the relevant claim language in the small element it chose was not amended. Ericsson, Inc. v. Harris Corp., 352 F.3d 1369, 1375 (Fed. Cir. 2003).

105 This is especially true when the court concludes that the proper meaning of a claim term is the combination of all the definitions found in different dictionaries, as it did in Bilstad v. Wakalopulos, 386 F.3d 1106 (Fed. Cir. 2004); see also Texas Digital Sys., Inc. v. Telegenix, Inc., 308 F.3d 1193, 1193 (Fed. Cir. 2002).

106 Indeed, Glynn Lunney has argued that this is precisely the direction the Federal Circuit has taken in the last 15 years, though he does not discuss the role of element size. Glynn S. Lunney, Jr., Patent Law, the Federal Circuit, and the Supreme Court: A Quiet Revolution, 11 SUP. CT. ECON. REv. 1, 38 (2004).

107 For a general discussion of the tradeoffs patentees face in seeking broader claims, see F. Scott Kieff, The Case for Registering Patents and the Law and Economics of Present Patent-Obtaining Rules, 45 B.C. L. REV. 55, 102-03 (2003). 
broad indeed. Whether a broad patent is good or bad for a patentee depends on whether infringement or invalidity is a more significant issue in any given case. Broad patents are hard to avoid infringing but easier to invalidate, both because any prior art within the reach of the patent will anticipate it, and because the patentee will have to disclose more in order to comply with the requirements of enablement and written description. ${ }^{108}$ For patents in box 4 , where the quanta are small and each is understood at a low level of abstraction, the situation is the reverse-patents will be narrow, and hence easier to avoid but harder to invalidate.

The situation in boxes 2 and 3 is more complex. In box 2 , the courts break the invention into small chunks (often individual words), which push in the direction of validity but no infringement. But by reading those words at a high level of generality ("fastener" rather than "screw"), the courts permit the patent to be applied to a variety of different things within each individual quantum. The result is a patent with a rigid framework-there may be thirty different elements that all must coincide in order to find infringement--but with flexibility in what constitutes each element. For box 3, the result is the opposite. There are relatively few chunks, but each is construed narrowly, so that while only a few elements need to be included, each must be included more or less exactly as specified. Boxes 2 and 3 produce patents of less determinate scope than boxes 1 and 4 , because the two effects we have described are pushing in different directions.

\section{B. Is There a Right Answer?}

What, then, is the "right" size of an element? The "right" level of abstraction at which to understand a patent term? Unfortunately, there may be no good answer to these questions. To understand why, we will situate the two indeterminacies we have discussed within the broader framework of claim construction.

Interpretation of texts is of course not unique to claim construction. The interpretive practices that we have identified here are situated within a broader universe of textual interpretation. A vast literature addresses the interpretation of literary and sacred texts. Some of this scholarship has found its way into discussion of the meaning of legal texts, applying general theories of textual meaning and literary analysis to the interpretive processes used by courts. While the practice of claim construction is perhaps unique in its systematic mapping of text onto a physical analog or process, similar interpretive exercises occur whenever a court attempts to determine the scope of items or activities covered by other legally enforceable texts, such as the text of a statute or of a contract. A large body of scholarship has developed around these latter interpretive exercises, especially critiquing and analyzing the process of constitutional and statutory interpretation.

Curiously, relatively little of this literature has been applied to understand the practice of patent claim interpretation. The parallels to statutory or

10835 U.S.C. $\$ 112(2000)$. 
contractual interpretation have been noted by a handful of recent commentators. Rob Merges has discussed the parallels between the "ordinary meaning" approach to claims interpretation and the now-discredited "four corners" approach to the interpretation of contract terms, by which courts attempted to give meaning to contractual terms without looking outside the "four corners" of the document. 109 As praxis and scholarship in contracts long ago discovered with regard to parol evidence, such meaning simply cannot be found without reference to context that lies beyond the document itself. Indeed, in the interpretation of claims, the reliance of the Federal Circuit on both the specification and the prosecution history to determine meaning in at least some cases is a tacit admission of this fact.

The process of determining meaning with reference to context implicates the distinction, suggested by Corbin, between interpretation and construction. Under this view, courts first interpret a term by selecting a meaning for it, and then construe the term by applying that meaning to the situation, thus giving the meaning legal effect. Merges notes that courts tend to characterize claim construction in a similar manner, beginning first with interpretation of a claim and then application of the interpretation to the accused device. Indeed, the procedure dictated by Markman attempts to formally bifurcate these steps by assigning the interpretive duty to the judge and the application to the jury. ${ }^{10}$

But Merges also notes that the initial interpretive process will largely dictate or drive the outcome of application in either contractual or claim interpretation. Quoting Hans-Georg Gadamer, ${ }^{111}$ Merges points out that it is essentially impossible to separate the steps of interpretation and application, as the interpretive process will always be undertaken with an eye toward the application, or final result, of a legal determination. ${ }^{12}$ This is apparent in the Markman process. Lawyers propose interpretations of claim terms with an eye toward the outcome they will produce. Judges sometimes try to construe claims in a vacuum, but increasingly want to know why it matters which word they choose. And a judge's decision will effectively take the infringement decision away from the jury altogether in most cases by selecting a claim interpretation so constrained that it leaves no room for more than a single outcome. Indeed, if a judge's construction doesn't have this effect, it likely means the patent lawyers on one side or the other haven't done their job.

Other commentators have seen closer parallels to theories developed in the context of statutory interpretation. Professor Nard has mapped the interpretive approaches common in statutory and constitutional analysis to those displayed by judges in the Federal Circuit. ${ }^{113}$ Drawing on Wittgenstein's theories of situated meaning, Nard criticizes what he has dubbed the hypertextualist wing of the Federal Circuit for limiting their interpretive view to the intrinsic

109 MERGES \& DUFFY, supra note 8, at, $906-07$.

110 Markman v. Westview Instruments, Inc., 517 U.S. 370, 391 (1996).

111 Hans-Georg Gadamer, Truth and Method 320-340 (Joel Weinsheimer \& Donald G. Marshall trans., 2d rev. ed. 1989) (1960).

112 MERGES \& DUFFY, supra note 8, at 907-08.

113 Craig Allan Nard, $A$ Theory of Claim Interpretation, 14 HARV. J.L. \& TECH. 1, 44 
evidence found within the patent itself and its prosecution history. ${ }^{114}$ Since language is situated in a complex network of shared social understanding, Nard argues that it is preferable to look at extrinsic evidence regarding the common use or meaning of particular claim terminology. ${ }^{115}$ Only when a claim is "ambiguous" will hypertextualists look to extrinsic evidence for clarification of meaning. But since claims are always ambiguous in the sense that they are susceptible to a range of meanings, examination of their broader context should always be appropriate. ${ }^{116}$

These analyses, whether looking to contractual or statutory interpretation, dramatically highlight the folly of assuming that the text of a patent claim, or any other text, has some readily discernible "plain" or "ordinary" meaning. Both Merges and Nard show the futility of believing that the meaning of a claim can be considered in isolation-Merges by arguing that the exercise is inevitably outcome driven, and Nard by arguing that the exercise is inevitably situated within a broader social context. This will hardly be news to the legions of analysts who have considered the interpretation of legal texts in other arenas. They have long known that the employment of dictionaries and other attempts at assigning "plain meaning" cannot avoid the problem of subjectivity of language, if only because decision makers must choose among different definitions based on their own subjective understanding of meaning. ${ }^{17}$

Much of the available analysis of claim interpretation critiques the manner in which a court arrives at a particular level of abstraction for claim elements, arguing that the choice of abstraction should be guided by intrinsic or extrinsic evidence or both. The literary interpretive tradition is helpful in demonstrating that neither kind of evidence eliminates the inherent ambiguity of the text. Were there no such ambiguity, or were this or that dictionary or index definitive, we would not require the application of human judgment to decide how broad or narrow the meaning of a given element will be. But all such arguments assume that ultimately a judge will in fact choose some level of abstraction and focus on the factors that influence the choice, while largely overlooking the nature of the choice itself.

A further complication is that claim construction inevitably takes on the character of endless recursion. In the process of giving meaning to the claims, courts in essence generate "meta-claims" by interpreting the words of patent claims using other, different words - for example, using the words of a dictionary definition to define a word found in a claim. Once a court defines the words of the claim in terms of other words, litigants will proceed to dispute over what those other words of the "meta-claim" themselves mean. ${ }^{118}$ The new

114 Id. at 4-12.

115 Id. at 82.

116 Ironically, Nard's argument in 2000 might be thought to support resort to dictionaries, but in 2004 dictionaries have taken the place of the intrinsic record as the font of hypertextualism.

117 William N. Eskridge, Jr., Gadamer/Statutory Interpretation, 90 CoLUM. L. REV. 609,679 (1990).

118 Thus, in Lockheed Martin Corp. v. Space Systems/Loral, Inc., 324 F.3d 1308, 1319 (Fed. Cir. 2003), the district court construed the claim phrase "varies sinusoidally" to mean 
words may be no more capable than the original ones of being mapped to a process or device. This fight over the construction of the words construing the claim points up the inherent indeterminacy of the effort to get certainty in meaning when applying words to things. 119

As if all this weren't bad enough, our Article shows two new axes on which patent claim construction (and related analyses such as the doctrine of equivalents) are necessarily indeterminate. Even if we could get it right with confidence, defining the meaning of words in terms of other words won't help us choose a level of abstraction at which to map those words to things. Nor will it give us any guidance as to the right quantum within which to define the terms. The problems we identified in Parts II and III heap ambiguity upon ambiguity and leave us with little confidence that any court, no matter how well-informed and well-intentioned, can produce a predictable, replicable answer.

\section{Dealing With the Lack of a Right Answer}

If there is no determinate answer-if the choices of levels of abstraction and quantum size are inherently ambiguous, or worse, made unconsciouslythen the whole search for a "plain" or "ordinary" or "settled" meaning of patent claims is doomed to failure, regardless of whether we look to the dictionary or to the patent specification or to the views of the person having ordinary skill in the art (PHOSITA). And if the words of claims truly are indeterminate, placing the burden of that ambiguity on the patent owner simply leads to unduly narrow claims, just as placing the burden on the accused infringer leads to unduly broad claims. What then?

Much of the difficulty that arises out of such indeterminacy comes from the practice of peripheral claiming and the process of claim construction that accompanies it. The idea behind peripheral claiming, which U.S. patent law adopted in the 1870 's, 120 was to establish the "metes and bounds" of the

\footnotetext{
"a variation in a sine-shaped curve that passes through zero." The parties did not dispute this definition, but disagreed vigorously over what it meant to "pass through zero" in the context of the satellite orbit of the invention. Id. The Federal Circuit ultimately had to resolve this dispute by finding a particular meaning of an orbital sine wave passing through zero, requiring "the capacity of the transverse momentum wheel to accelerate in one direction, slow to zero, and rotate in the opposite direction." Id. at 1321.

119 If we had not already adopted a quantum mechanics metaphor for this paper, we might here draw on an analogy to mathematician Kurt Gödel's indeterminacy theory, showing that a system of expression that is powerful enough to describe itself will include at least one unprovable statement. See KURT GÖDEL, ON FORMALly UNDECIDABLE Propositions of Principia Mathematica and Related Systems (B. Meltzer trans., Oliver \& Boyd 1962) (1931). One of the corollaries to Gödel's Incompleteness Theorem predicts indeterminacy in an expressive system as rich as the English language. See JACOB BRONOWOSKI, THE IDENTITY OF MAN (1965) (summarizing the Church-Turing-Tarski hypothesis). But as we have, we won't.

120 See Merrill v. Yeomans, 94 U.S. 568 (1877) (adopting claims as limiting the invention); The Wood-Paper Patent, 90 U.S. (23 Wall.) 566, 606 (1873). See generally William Redin Woodward, Definiteness and Particularity in Patent Claims, $46 \mathrm{MICH}$. L. REV. 755, 760-62 (1948) (describing the growth of peripheral claiming between 1853 and 1877).
} 
invention in a way analogous to real property deeds. ${ }^{121}$ But patent law has provided none of the certainty associated with the definition of boundaries in real property law. The Patent and Trademark Office doesn't devote its efforts to construing the claims of the patents it issues. ${ }^{122}$ Claim construction gets reserved for litigation and license negotiations. Every case involves a fight over the meaning of multiple terms, and not just the complex technical ones; recent Federal Circuit cases have had to decide plausible disagreements over the meanings of the words "a,"123 "or," 24 "to,"125 "on,",126 "about,"127 "including," 128 and "through,", to name but a few. Claim construction is sufficiently uncertain that many parties don't settle a case until after the court has construed the claims, because there is no baseline for agreement on what the patent might possibly cover. ${ }^{130}$ Even after claim construction, the meaning of the claims is uncertain. People fight over the meaning of the constructions in a sort of "meta" claim construction. And the Federal Circuit reverses roughly a third of the claim constructions presented to it on appeal, ${ }^{131}$ a far larger percentage than its general reversal rate. The idea of setting out clear boundaries to warn the public of what is and is not claimed-the "notice function" of patents that has received so much attention in recent years ${ }^{132}$ simply isn't working. ${ }^{133}$

121 See, e.g., CAE Screenplates, Inc. v. Heinrich Fiedler GmbH \& Co., 224 F.3d 1308, 1319 (Fed. Cir. 2000) (one of many cases drawing this analogy).

122 And arguably it shouldn't. Cf. Mark A. Lemley, Rational Ignorance at the Patent Office, 95 Nw. U. L. REV. 1495 (2001).

123 N. Am. Vaccine, Inc. v. Am. Cyanamid Co., 7 F.3d 1571, 1581 (Fed. Cir. 1993).

124 Kustom Signals, Inc. v. Applied Concepts, Inc., 264 F.3d 1326, 1331 (Fed. Cir. 2001).

125 Cybor Corp. v. FAS Techs., Inc., 138 F.3d 1448, 1459 (Fed. Cir. 1998); Chef Am., Inc. v. Lamb-Weston, Inc., 358 F.3d 1371, 1374-75 (Fed. Cir. 2004).

126 Senmed Inc. v. Richard-Allan Med. Indus. Inc., 888 F.2d 815 (Fed. Cir. 1989).

127 Merck \& Co. v. Teva Pharms., 395 F.3d 1364 (Fed. Cir. 2005); id. at 1378 (Rader, J., dissenting).

128 Toro Co. v. White Consolidated Indus., Inc., 199 F.3d 1295, 1300 (Fed. Cir. 1999).

129 Sage Prods., Inc. v. Devon Indus., Inc., 126 F.3d 1420, 1430 (Fed. Cir. 1997).

130 Kimberly Moore's comprehensive patent litigation database shows that the majority of patent cases are disposed of quite early, presumably by settlement. This likely includes a large number of cases that are never really litigated on the merits, but in which a suit was filed for strategic reasons in a licensing discussion or multiple suits were filed and the cases ultimately consolidated somewhere.

131 The definitive study is Kimberly A. Moore, Are District Court Judges Equipped to Resolve Patent Cases?, 15 HARV. J.L. \& TECH. 1, 2 (2001) (finding that the Federal Circuit reverses district court claim constructions $33 \%$ of the time). Moore updated her study in a paper in this symposium, and showed that the problem is getting worse, not better. Kimberly A. Moore, Markman Eight Years Later: Is Claim Construction More Predictable?, 9 LEwIS \& Clark L. REV. 231 (2005); see also Christian A. Chu, Empirical Analysis of the Federal Circuit's Claim Construction Trends, 16 BERKELEY TECH. L.J. 1075, 1090 (2001) (finding a reversal rate between $30 \%$ and $38 \%$, depending on the assumptions used, and noting that the rate was increasing).

132 See, e.g, PSC Computer Prods., Inc. v. Foxconn Int'l, Inc., 355 F.3d 1353, 1358 (Fed. Cir. 2004); Festo Corp. v. Shoketsu Kinzoku Kogyo Kabushiki Co., 344 F.3d 1359, 1367 (Fed. Cir. 2003); Sage Prods., Inc. v. Devon Indus., Inc., 126 F.3d 1420, 1424 (Fed. Cir. 1997). Long before the creation of the Federal Circuit, the Supreme Court itself 
Given the lack of a clear boundary, the purposes of peripheral "notice claiming" might yet be served by narrowly construing claims against the drafter in cases of indeterminacy. This discourages the inventor from attempting to take advantage of the natural indeterminacy of language by purposefully introducing ambiguities. At the same time, where indeterminacy exists-as it inevitably will-courts will be required to shape the appropriate boundary via the doctrine of equivalents in those cases where the technical boundary of the claim was in fact unforeseen or unforeseeable. If they don't, patent claims will be unduly narrow and quite easy to evade.

The result will be a literal claim scope that is often narrow, coupled with a reinvigorated doctrine of equivalents. Use of the doctrine of equivalents won't get rid of the indeterminacy, of course-nothing can. But it would permit the courts to pay attention to the issues that really matter in deciding patent scope-the importance of the invention in the industry, the nature of the technology, how this invention relates to others in producing marketable products, and the relationship between the patentee's invention and the accused device. It might also have the salutary effect of permitting some industryspecific variation in the scope of patent claims in practice, either by applying the long-dormant doctrine of pioneer patents or by treating the doctrine of equivalents as a policy lever. ${ }^{134}$

We note that such enhanced reliance on the doctrine of equivalents is not inconsistent with the Federal Circuit's recent efforts to cabin abuses of the doctrine. All of the court's doctrines limiting the doctrine of equivalentsprosecution history estoppel, dedication to the public domain, and avoiding the prior art-involve cases in which the effect of a choice in claiming was foreseeable. ${ }^{135}$ Where it is unforeseeable, or where there is plausible ambiguity,

emphasized the notice function, and expressed concern about "a zone of uncertainty which enterprise and experimentation may enter only at the risk of infringement claims." United Carbon Co. v. Binney \& Smith Co., 317 U.S. 228, 236 (1942).

133 For greater detail on this point, see John R. Thomas, Claim Re-Construction: The Doctrine of Equivalents in the Post-Markman Era, 9 LEWIS \& CLARK L. REV. 153, 154-55 (2005).

134 See Christopher A. Cotropia, "After-Arising" Technologies and Tailoring Patent Scope (Nov. 10, 2004) (unpublished manuscript on file with authors). Thus, one of the authors has wamed of the risks of applying the doctrine of equivalents too broadly in the software industry, where rapid generational changes mean that patent claims may end up covering accused devices that are far more advanced than the patentee could have conceived. Cohen \& Lemley, supra note 35 , at 53 . By contrast, arguably the courts should give the doctrine of equivalents more scope in biotechnology in order to give patentees adequate compensation for the cost, delay, and uncertainty of the biotechnology innovation process. See Dan L. Burk \& Mark A. Lemley, Tailoring InNovation Law: Shaping Patent POLICY FOR SPECIFIC INDUSTRIES (forthcoming 2005) (manuscript on file with authors).

135 The doctrine of prosecution history estoppel, which precludes a patentee who narrows her claims from later recapturing that ground under the doctrine of equivalents, Warner-Jenkinson Co. v. Hilton Davis Chem. Co., 520 U.S. 17, 40-41 (1997), contains an exception permitting the doctrine of equivalents to apply to technologies that were not reasonably foreseeable at the time the claims were changed. See Festo Corp. v. Shoketsu Kinzoku Kogyo Kabushiki Co., 535 U.S. 722 (2002); Festo Corp. v. Shoketsu Kinzoku Kogyo Kabushiki Co., 344 F.3d 1359 (Fed. Cir. 2003) (en banc); Matthew J. Conigliaro, Andrew C. Greenburg \& Mark A. Lemley, Foreseeability in Patent Law, 16 BERKELEY TECH 
courts are free to use the doctrine of equivalents to determine the boundary that the inventor could not plausibly have determined. We doubt that this movement toward a re-invigorated doctrine of equivalents could introduce any greater uncertainty into the claims construction process than is inherent in the cases as they stand already. ${ }^{136}$

Another implication of this inherent indeterminacy is that we should rethink patent law doctrines based on notice. Two such doctrines come to mind-the doctrine of willful infringement and the law of inducing infringement. Infringement is not willful unless the accused infringer knows it is actually infringing a valid patent. ${ }^{137}$ Similarly, a party cannot induce infringement unless it specifically intends that the conduct it encourages actually infringe a patent. ${ }^{138}$ But if we cannot reliably figure out the actual scope of a patent, it makes little sense to try to build legal rules around the fact that someone was put on notice of a patent. In fact, the willfulness doctrine has given rise to a cottage industry in which lawyers write opinion letters telling clients who learn of patents that they are not infringing those patents under a plausible claim construction. ${ }^{139}$ These letters always say the patent is either invalid or not infringed, something that is possible because of the uncertainty of claim construction and that makes the whole practice a rather unsavory game. Recognition that claim scope is simply indeterminate ex ante should lead us to try to put these doctrines on a more objective basis rather than to focus on notice. $^{40}$

L.J. 1045 (2001). The rule that the doctrine of equivalents cannot extend to cover the prior art, see, e.g., Wilson Sporting Goods Co. v. David Geoffrey \& Assocs., 904 F.2d 677, 683 (Fed. Cir. 1990), will not apply to later-developed technology, which by definition cannot be in the prior art. And the doctrine of dedication to the public domain, which prevents a patentee from covering under the doctrine of equivalents an implementation described in the specification but not claimed in the patent, Johnson \& Johnston Assocs. v. R.E. Serv. Co., 285 F.3d 1046, 1054 (Fed. Cir. 2002), also by definition will not apply to technologies not contemplated at the time the patent was filed.

136 Indeed, construction of means-plus-function claim language already proceeds in this way under 35 U.S.C. $\S 112(2000)$, and while it is far from certain, it does not appear to be significantly more uncertain than construction of ordinary claim language.

137 See, e.g., Aro Mfg. Co. v. Convertible Top Replacement Co., 377 U.S. 476, 488 (1964) (requiring, in the context of contributory infringement (which also imposes a knowledge requirement), a showing that the infringer knew the product it made "was both patented and infringing" to satisfy the knowledge requirement); Ryco, Inc. v. Ag-Bag Corp., 857 F.2d 1418, 1428 (Fed. Cir. 1988) (defining the test for willfulness as whether a defendant could have "any confidence that a court might hold the patent invalid or not infringed."). But see Sandisk Corp. v. Lexar Media, Inc., 91 F. Supp. 2d 1327, 1335 (N.D. Cal. 2000) (suggesting, incorrectly in our view, that knowledge of the patent and of the infringing activity will suffice for liability).

${ }_{138}$ Manville Sales Corp. v. Paramount Sys., Inc., 917 F.2d 544, 551 (Fed. Cir. 1990). It is unclear whether intent to infringe a patent that you reasonably believe to be invalid can constitute inducement. See Mark A. Lemley, Inducing Infringement, _ U.C. DAVIS L. REV. (forthcoming 2005) (exploring this question).

139 For a discussion of this system and its problems, see Mark A. Lemley \& Ragesh K. Tangri, Ending Patent Law's Willfulness Game, 18 BERKELEY TECH. L.J. 1085 (2003).

${ }_{140}$ For suggestions along these lines, see, e.g., Knorr-Bremse Systeme Feur Nutzfahrzeuge GmbH v. Dana Corp., 383 F.3d 1337, 1348-52 (Fed. Cir. 2004) (Dyk, J., 
Finally, the inherent indeterminacy of language might paradoxically incline us to procedural mechanisms that force courts to make the determination earlier in litigation. If there is no right answer, we might spend less time searching for one and instead get an answer relatively quickly, using an early Markman hearing and perhaps an interlocutory appeal. ${ }^{41}$

\section{CONCLUSION}

Perhaps it is impractical to hope that the Federal Circuit-which has sought to cabin its own common-law authority within tight formal rules ${ }^{142}$ will recognize the inherent indeterminacy of patent claims and take such a step away from rules and toward standards. ${ }^{143}$ But one thing is clear: if the court is seeking certainty and predictability by turning to a more formal model of claim construction, ${ }^{144}$ it is unlikely to find them.

concurring in part and dissenting in part); Lemley \& Tangri, supra note 139 (discussing both their own proposal and Doug Lichtman's suggestions along these lines).

141 While commentators and even courts have argued for interlocutory appeals of Markman rulings, see TM Patents, L.P. v. IBM Corp., 72 F. Supp. 2d 370, 377 n.1 (S.D.N.Y. 1999), the Federal Circuit has never granted one. Ronald J. Schutz \& Jonathan D. Goins, Case Management Issues in Patent Litigation, 5 SEDONA CONF. J. 1 (2004).

142 For discussions, see, e.g., Dan L. Burk \& Mark A. Lemley, Policy Levers in Patent Law, 89 VA. L. Rev. 1575, 1671-75 (2003); Arti K. Rai, Engaging Facts and Policy: A Multi-Institutional Approach to Patent System Reform, 103 CoLUM. L. REV. 1035, 1103-10 (2003); John R. Thomas, Formalism at the Federal Circuit, 52 AM. U. L. REV. 771, 773 (2003).

143 Similarly, the recent House of Lords decision in Kirin-Amgen. Inc. v. Hoechst Marion Roussel, Ltd., [2004] UKHL 46 paras. 41-44, rejecting the doctrine of equivalents altogether in U.K. law because of its great confidence in the meaning of claim terms, seems a step in the wrong direction.

144 For suggestions that this is what is occurring, see R. Polk Wagner \& Lee Petherbridge, Is the Federal Circuit Succeeding? An Empirical Assessment of Judicial Performance, 152 U. PA. L. REv. 1105 (2004). 